\title{
THE REDUCTION OF GREEN HOUSE GASES EGRESSIONS DUE TO COVID-19 AND THE ASCENT OF RENEWABLE ENERGY GENERATION IN MALAYSIA
}

\author{
${ }^{1}$ Janasekaran, S.*, ${ }^{1}$ Tayier, W. \\ ${ }^{1}$ Centre for Advanced Materials and Intelligent Manufacturing, Faculty of Engineering, Built \\ Environment and Information Technology, SEGi University, 47810 Petaling Jaya, Selangor, \\ Malaysia. \\ * Corresponding Author: shaminijanasekaran@segi.edu.my TEL: (603)- 61451777
}

\begin{abstract}
The current global pandemic COVID-19 definitely left a relatively large forceful consequence on humanity's mortality rate and economical records present-day. As reported or stated by the World Health Organization (WHO), the infectious agent gives rise to extreme danger to the wellbeing of a certain prone to death group (elderly people specifically). Nonetheless, there are several dissensions deem to be the cause of the pathogen and its host. The virus has forced most countries to take action by enforcing strict curfew legal guidelines and terminated most operations in the industrial and entertainment sectors. The objective of this study is to exhibit the inherent capacity and the effective consequences of the virus towards ecology together with extending inexhaustible free power source technology. Malaysia took measures against COVID-19 by carrying out Movement Control Order (MCO) earlier in March 2020. The enforcement of the MCO has shown a decrease in the contamination percentage, specifically pollution of the atmosphere. The statistical comparison indicated that the carbon dioxide $\left(\mathrm{CO}_{2}\right)$ emissions reached $8 \mathrm{Mt} \mathrm{CO}_{2}$ eq from the January to March in 2020 where the greenhouse emission was significantly higher as compared to the $\mathrm{CO}_{2}$ emissions in April 2020, at $1 \mathrm{Mt} \mathrm{CO}_{2}$ eq. The renewable energy sector has grown due to the reduction of carbon gases emissions from fossil fuels and other natural resources. Therefore, the reduction of the greenhouse gas (GHG) emissions encouraged the shift towards renewable energy sources and provided the opportunity for expending solar energy in Malaysia and other countries during the pandemic.
\end{abstract}

Keywords: Photovoltaic; Free energy; Green-house gases egression; COVID-19; Ecological contamination; Pandemic. 


\section{Introduction}

On November 3rd 2020, the World Health Organization has made it widely known that Coronavirus disease 2019 (COVID-19) is an epidemic that is geographically widespread throughout the world, in other words, a global pandemic. The estimated positive cases are 25,040,371 cases in addition to 843,727 fatalities in China and 114 countries (Harapan, 2020). Short but severe course cardiorespiratory condition, Covid-19 has dispersed widely throughout the planet. Making it a dangerous agent capable of producing infections at a high rate which has affected public health globally. This unfortunate circumstances lead to destructive consequences, resulting in the closure and failure of most businesses (Klemeš et al., 2020). On 12 December 2019, the first COVID-19 patient was hospitalized (Ryu et al., 2020). Since then, the fatality rate of this illness had risen to 250,000 within early 2020 in May. Mutually with the highest degree of recorded death toll had to be Spain, Italy, and the United States (Guo et al., 2020).

The disease spread has drastically affected the energy private sectors which caused a series of problems such as delay in supply chains and troubles of stock markets etc. Meanwhile, the outbreak brought limited social freedom in which contributed to the reduction of employment rate and investment acts in energy sectors due to the uncertainty. Therefore, many countries demonstrated clear energy incentives (Eroğlu, 2020). This gives an opportunity to shift the power mix from traditional power to solar energy, which allows a healthier and faster method of recovery. Solar power has been shown to help companies cut electricity bills by up to 30-50 percent while satisfying power source requests through supplying sufficient power for everyday use (Kabir et al., 2018).

\section{Malaysia's Electricity Expenditure and GHG Egression}

Evolution of renewable energy in Malaysia has been challenging due to absence of incentives for utilities. Currently, the utilized renewable energy account for only $8 \%$ of total energy fields in Malaysia including solar energy, hydroelectric and biomass. According to the statement of Malaysian Investment Development Authority (MIDA), the discovery of renewable energy source will be dominated or arrived at $20 \%$ by the 2025 . Furthermore, the electricity produced from the solar radiation has reached $4.7 \times 6.5 \mathrm{kWh} / \mathrm{m}^{2}$ per day due to the advantages of local weather conditions (hot and humid). Therefore, a large percentage of local electricity is 
produced from solar energy in which have also been popular in Malaysia. Referring to the small and medium enterprises (SME) industry in Malaysia, the allocation of total electric energy demand is dominated by the heat ventilation and air conditioning (HVAC) system. For instance, the HVAC in buildings and other industries dominated 59\% and 29\% of the total energy consumption in Malaysia respectively. Meanwhile, the International Renewable Energy Agency (IRENA) reported the building and other industries consumed up to $90 \%$ and $24 \%$ of total energy consumption respectively as shown in Figure 1. Due to the rise in electricity demand in Malaysia, the energy consumption has grown which significantly increases greenhouse emission as shown in Table 1 (Mahesh et al., 2020). Over the last few decades, energy demand in Malaysia has risen to support the nation's steady growth in the productive capacity of the economy. The demand for energy is likely to spike in the coming years, making GHG emissions a big concern as non-renewable fuel sources primarily methane, coal, and crude oil remains the primary contributor of electricity production. This causes a rise in power usage while disregarding the negative impacts to the environment in order to meet these demands. The Paris Agreement had contributed to a more progressive nation's industrial development by increasing awareness on the greenhouse effects caused by energy use among the international community.

Note that the transport industry relies almost exclusively on fuels dependent on petroleum. (Wang et al., 2019). The largest contributor to $\mathrm{CO}_{2}$ emissions is the transport industry, closely followed by separate energy sectors, primarily driven by crude oil such as petroleum, methane, and bituminous coal. Since the end of the 1990s and by 2020, the GHG emissions was significantly high, and emissions rate reached $1600 \mathrm{Mt} \mathrm{CO}_{2}$ eq /per year (Brief, 2020). By reducing GHG egressions from the transport industry, the pandemic. The Canadian transport industry's GHG egressions elevated to 19 percent between 2000 to 2017. In March, April, May, and June, nearly $45 \mathrm{Mt}$ of $\mathrm{CO}_{2}$ equivalent would have been saved by shutting down the transport sector. In Table 2, it can be seen that the carbon emission in variety of natural resources were slightly low in 2019 in where the renewable energy such as solar energy had more possibility to replace non-renewable energy. Meanwhile, Table 2 also indicated that the carbon emission will generally decrease by $20 \%$ in 2020 as the consumption of natural resources decreases which gives the opportunity for renewable energy sectors to improve energy technology in hopes of totally replacing the use non-renewable energy in Malaysia during the Covid-19 pandemic (Kaman et al., 2019). 

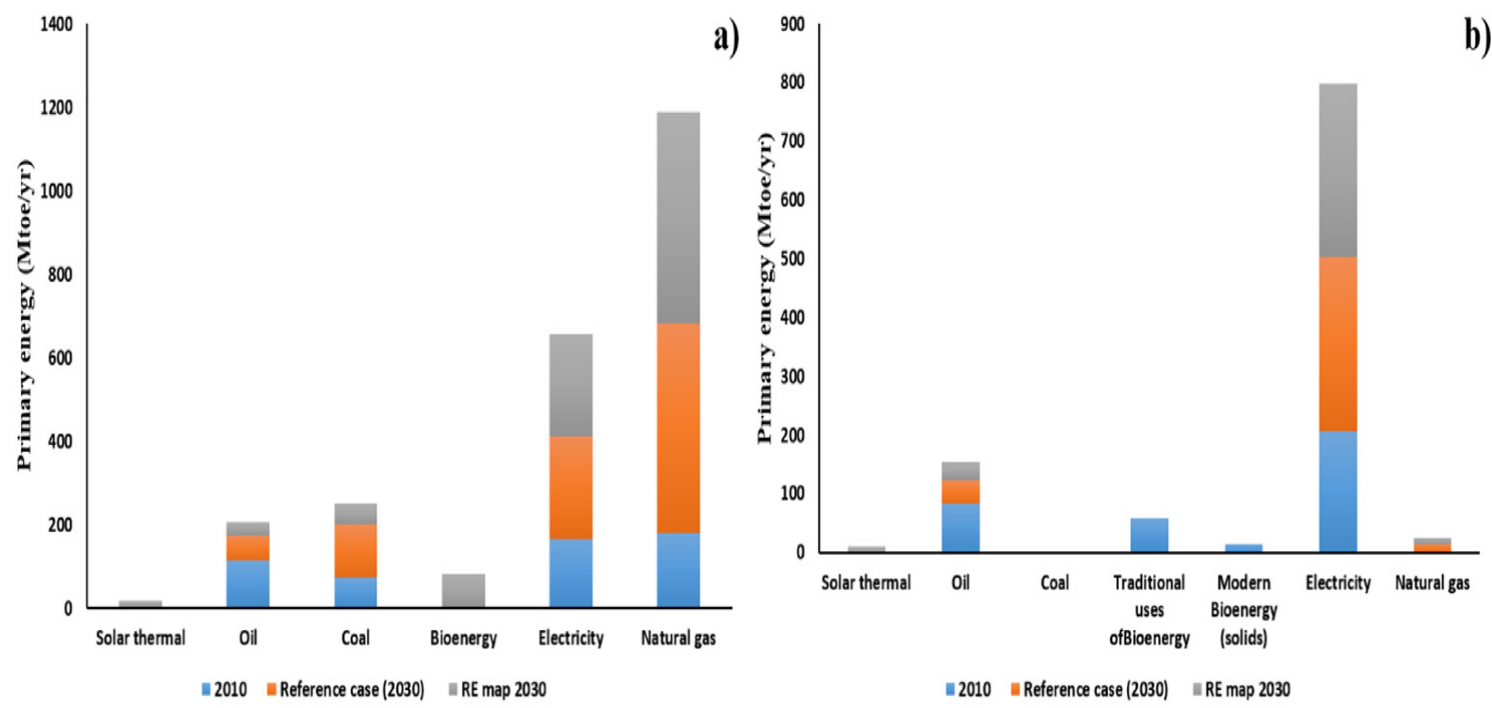

Figure 1. Total energy demand from different renewable sources for; (a): industry, (b): buildings (Mahesh et al., 2020)

Table 1. Statistics of installed capacity and electricity generation in Malaysia compared to the rest of the world from 2010 to 2019 (Mahesh et al., 2020)

\begin{tabular}{|c|c|c|c|c|}
\hline Year & $\begin{array}{c}\text { Installed } \\
\text { capacity, } \\
\text { MW } \\
\text { (Malaysia) }\end{array}$ & $\begin{array}{c}\text { Electricity } \\
\text { generation, } \\
\text { GWh } \\
\text { (Malaysia) }\end{array}$ & $\begin{array}{c}\text { Installed } \\
\text { capacity, } \\
\text { MW (Rest of } \\
\text { the world) }\end{array}$ & $\begin{array}{c}\text { Electricity } \\
\text { generation, } \\
\text { GWh (Rest of } \\
\text { the world) }\end{array}$ \\
\hline $\mathbf{2 0 1 0}$ & 0.54 & 0.67 & 40276.67 & 32160.38 \\
\hline $\mathbf{2 0 1 1}$ & 0.54 & 0.67 & 72029.69 & 62443.37 \\
\hline $\mathbf{2 0 1 2}$ & 23.10 & 30.88 & 101511.21 & 96351.81 \\
\hline $\mathbf{2 0 1 3}$ & 97.12 & 53.74 & 135740.13 & 131701.81 \\
\hline $\mathbf{2 0 1 4}$ & 165.78 & 190.51 & 171518.92 & 183943.37 \\
\hline $\mathbf{2 0 1 5}$ & 229.10 & 275.41 & 217242.34 & 242371.88 \\
\hline $\mathbf{2 0 1 6}$ & 278.80 & 326.23 & 290961.18 & 314053.25 \\
\hline $\mathbf{2 0 1 7}$ & 376.07 & 333.02 & 383597.83 & 425872.64 \\
\hline $\mathbf{2 0 1 8}$ & 536.02 & N/A & 483078.20 & N/A \\
\hline $\mathbf{2 0 1 9}$ & 882.02 & N/A & 580139 & N/A \\
\hline
\end{tabular}

Table 2. $\mathrm{CO}_{2}$ (in Mt) emissions of fossil combustibles (Malaysia)

\begin{tabular}{|l|c|c|c|}
\hline \multicolumn{1}{|c|}{ Year } & $\mathbf{2 0 1 8}$ & $\mathbf{2 0 1 9}$ & $\mathbf{2 0 2 0}$ Forecast \\
\hline Other Liquid Oils \& Petroleum & 2,373 & 2,354 & 2,189 \\
\hline Methane & 1,636 & 1,689 & 1,670 \\
\hline Bituminous Anthracite & 1,260 & 1,084 & 8,85 \\
\hline Sum of Power Source & 5,280 & 5,138 & 4,755 \\
\hline
\end{tabular}


Currently, many industrial and manufacturing sectors have been introducing green energy strategies. The manufacturers play a part in promoting the sustainable energy in the manufacturing consumption and this will influence the predominant free energy economic policies of every participating nation. The high concentration of these gases in particular, is one of the most critical environmental challenges affecting developed countries. It is important to remember that while certain GHG emissions have declined due to the pandemic, this reduction does not affect the overall atmospheric amount of GHGs accumulated for decades. In the countries' economies, there is a chance of recovering the nation's economy as the pandemic ends which could potentially result in the inflation of GHG emissions (Sharma \& Dhar, 2018). Renewable Energy (RE) was introduced by Malaysia acting as the fifth fuel plan of action under a 2001 Mixed Energy Plan on the underside of National Energy Policy. It aims to generate 500 MW of grid-on electricity of RE capital in 2019 (Kabir et al., 2018). Considering resources such as timber, solar, including water supplies, Malaysia has considerable RE reserves. At COP15 Copenhagen, Denmark, Malaysia vowed intentionally to the reduction of GHG egressions to a point of 40 percent by 2025 in contrast to 2005 .

\section{COVID-19's Effect on Solar Energy in Malaysia}

The global pandemic has taken hundreds of thousands of lives in addition to having a huge influence on the world economy. Even six months after the pandemic, the world only needs to recover from the damage suffered by the pandemic. In reality, it has affected the global economy, and Malaysia's industries are not exempted. If energy production through PV panels is improved, amassed solar power production can be expected. Air pollution has decreased dramatically in line with the MCO legislation adopted throughout Malaysia since the middle of March 2020. As the pandemic continues to have a cognitive impact upon GDP vigorously, the Ministry of Energy and Natural Resources (KeTSA) Committee has made widely known that the renewable energy proportion is to be prioritised as an urgent means of boosting the Malaysian economy. To encourage renewable energy investment, KeTSA decided to launch a competitive tender mechanism onto the Large-Scale Solar (LSS) program that ushered the Malaysian Electricity Industry. The growth in PV installations between those years have resulted in the country's expanded employment opportunities. Within 2020, the Malaysian governing body aims for advantages as much as possible from investments in renewable energy to stimulate economic development. Also, $91 \%$ concerned with the global populace exists in 
nations with inferior quality of air reaches allowable limitations (Héroux et al., 2015). Air quality is critical for the well-being of humans.

The Malaysian government is interested in the development of solar energy as it could be the key towards a low carbon society during Covid-19, with the help of industrial and manufacturing fields which plays an important role to accomplish to this version. Malaysia plans to invest RM5 billion (US\$1.1 billion) into solar power projects in order to achieve a capacity of $1400 \mathrm{MW}$ by the end of 2020 through initiatives such as Solar PV installation facilitation programme that focuses on generating $50 \mathrm{kWp}$ installed capacity of GridConnected Photovoltaic (GCPV) to generate electricity and connected to the power supply to the building common area. Under the Off-Grid Photovoltaic (OGPV) project, a $1.2 \mathrm{kWp}$ solar PV was equipped for 12 houses to access electricity including battery storage and basic electrical appliances which encourages a cleaner environment avoiding greenhouse emission. (Vaka et al., 2020). Later in 2019, strict social distancing steps were adopted in Hubei province (China). The major economic practices of the world have been affected by these interventions. This led their manufacturing processes to be abandoned by power stations and industrial facilities. The use of cars has also dramatically declined. Most in this regard brought about an impressive decrease in $\mathrm{NO}_{2}$ in addition to granular sediment concentrations coupled together with a width of fewer than $2.5 \mu \mathrm{m}$ (PM 2.5) within the largest cities in China (ZambranoMonserrate et al., 2020). After officials ordered citizens into staying home towards stopping this outbreak, air pollution fell significantly in other parts of the planet, such as Europe. The use of vehicles has declined, thus lowering GHG egression with major factories and other routine activities have ceased.

In the interval times of March 2019 and March 2020, the irradiance levels were compared in the other countries. The findings demonstrated the positive existence of the coronavirus, which increased the level of radiation and the relative magnitude of energy. During the decreasing of $\mathrm{NO}_{2}$, the temperature of earth surface will be significantly drop at $0.01{ }^{\circ} \mathrm{C}$ by the year 2025 according to the statical analysis from the national science departments (Forster et al., 2020). Trends in $\mathrm{NO}_{2}$ often lead to an undistinguished temperature change trend owing to the reduction of nitrate formation in atmospheric aerosols using cutting-edge technology such as laser detector and machine learning. 


\section{Conclusion}

Renewable energy is abundant in the universe, in particular, wind and also solar ray energy generates electricity in absence of producing carbon dioxide egressions Malaysia's domestic energy policies and plans are targeted at making a major share of inexhaustible resources to electricity production. With the implementation of this legislation on carbon footprint such as $\mathrm{CO} 2$ emission, a significant reduction air pollution has been observed. Thus, the largest amount of sunlight in photovoltaic (PV) systems is hitting the Earth, radiating solar panels, and contributing to an increase in the output of electricity. Finally, solar energy is a technology that is advanced, clean, and renewable and is seen as a potential pioneer in energy choices. It is clean, inexpensive, and easy. Perhaps notably, while it does not produce greenhouse gases during service and aims to combat climate change, it is environmentally sustainable. The data presented have demonstrated substantial energy savings and GHG reductions related to pandemics.

\section{Acknowledgement}

The authors would like to thank anonymous reviewers for their input and thank SEGi University for giving platform to perform this study.

\section{References}

Brief, P. (2020). Coronavirus tracker: the latest figures as countries fight Covid-19 resurgence. Retrieved 23 November 2020, from https://www.ft.com/coronavirus-latest

Eroğlu, H. (2021). Effects of Covid-19 outbreak on environment and renewable energy sector. Environment, Development and Sustainability, 23(4), pp.4782-4790.

Forster, P.M., Forster, H.I., Evans, M.J., Gidden, M.J., Jones, C.D., Keller, C.A., Lamboll, R.D., Le Quéré, C., Rogelj, J., Rosen, D. and Schleussner, C.F. (2020). Current and future global climate impacts resulting from COVID-19. Nature Climate Change, 10(10), pp.913-919.

Guo, Y.R., Cao, Q.D., Hong, Z.S., Tan, Y.Y., Chen, S.D., Jin, H.J., Tan, K.S., Wang, D.Y. and Yan, Y. (2020). The origin, transmission and clinical therapies on coronavirus disease 2019 (COVID-19) outbreak-an update on the status. Military Medical Research, 7(1), pp.1-10.

Harapan, H., Itoh, N., Yufika, A., Winardi, W., Keam, S., Te, H., Megawati, D., Hayati, Z., Wagner, A.L. and Mudatsir, M. (2020). Coronavirus disease 2019 (COVID-19): A literature review. Journal of infection and public health, 13(5), pp.667-673.

Héroux, M.E., Anderson, H.R., Atkinson, R., Brunekreef, B., Cohen, A., Forastiere, F., Hurley, F., Katsouyanni, K., Krewski, D., Krzyzanowski, M. and Künzli, N. (2015). Quantifying 
the health impacts of ambient air pollutants: recommendations of a WHO/Europe project. International journal of public health, 60(5), pp.619-627.

Kabir, E., Kumar, P., Kumar, S., Adelodun, A.A. and Kim, K.H. (2018). Solar energy: Potential and future prospects. Renewable and Sustainable Energy Reviews, 82, pp.894-900.

Kaman, Z.K., Salleh, S.F. and Ishak, W.W.M. (2019). Renewable energy and policy development IN Malaysia. Asia Proceedings of Social Sciences, 4(2), pp.76-78.

Klemeš, J.J., Van Fan, Y., Tan, R.R. and Jiang, P. (2020). Minimising the present and future plastic waste, energy and environmental footprints related to COVID-19. Renewable and Sustainable Energy Reviews, 127, p.109883.

Mahesh, S., Ball, J.M., Oliver, R.D., McMeekin, D.P., Nayak, P.K., Johnston, M.B. and Snaith, H.J. (2020). Revealing the origin of voltage loss in mixed-halide perovskite solar cells. Energy \& Environmental Science, 13(1), pp.258-267.

Ryu, S., Chun, B.C. and of Epidemiology, K.S. (2020). An interim review of the epidemiological characteristics of 2019 novel coronavirus. Epidemiology and health, 42.

Sharma, P. and Dhar, A. (2018). Effect of hydrogen supplementation on engine performance and emissions. International Journal of Hydrogen Energy, 43(15), pp.7570-7580.

Vaka, M., Walvekar, R., Rasheed, A.K. and Khalid, M. (2020). A review on Malaysia's solar energy pathway towards carbon-neutral Malaysia beyond Covid'19 pandemic. Journal of Cleaner Production, p.122834.

Wang, Q., Jiang, R. and Zhan, L. (2019). Is decoupling economic growth from fuel consumption possible in developing countries?-A comparison of China and India. Journal of Cleaner Production, 229, pp.806-817.

Zambrano-Monserrate, M.A., Ruano, M.A. and Sanchez-Alcalde, L. (2020). Indirect effects of COVID-19 on the environment. Science of the total environment, 728, p.138813. 